\title{
KEBIJAKAN HUKUM PIDANA DALAM MENANGGULANGI PENYALAHGUNAAN BBM SUSBSIDI DI NUSA TENGGARA TIMUR ${ }^{1}$
}

\author{
Sigit Agung Susilo \\ Program Pasca Sarjana Universitas Nusa Cendana \\ Jl. Adi Sucipto - Penfui Kota Kupang 85001 \\ Email: rapssmooth1955@gmail.com
}

\begin{abstract}
Policy formulation criminal act of abuse of fuel subsidies and the application of criminal sanctions in the future. The methodology of this research is normative legal research. This research are expected contains a clear and complete for the criminal sanctions imposed against individuals and legal entities. The threat of punishment against officials who issue permits unauthorized or misuse of power. Criminal sanctions should be formulated not rigid but more flexible cumulative with the formulation of alternative or cumulative alternatives.
\end{abstract}

Keywords: Policy Formulation; Criminal sanctions.

\section{Abstrak}

Kebijakan formulasi tindak pidana penyalahgunaan BBM subsidi dan penerapan sanksi pidana dimasa yang akan datang. Penelitian ini menggunakan metode pendekatan yuridis normatif. Penelitian ini diharapkan memuat secara jelas dan lengkap mengenai sanksi pidana yang dijatuhkan terhadap individu dan badan hukum. Ancaman hukuman terhadap pejabat yang mengeluarkan ijin tidak sah atau menyalahgunakan kekuasaan. Sanksi pidana hendaknya dirumuskan tidak kaku kumulatif namun lebih fleksibel dengan perumusan alternatif atau kumulatif alternatif.

Kata kunci: Kebijakan Formulasi; Sanksi pidana.

A. Pendahuluan

1. Latar Belakang Permasalahan

Secara geografis Provinsi NTT adalah

Provinsi kepulauan maka dalam pendistribusian BBM sangat bergantung dengan kondisi cuaca, hal ini mengakibatkan timbulnya kendala dalam pendistribusian BBM sehingga menimbulkan keterlambatan dan kelangkaan bbm di pasaran. Kondisi geografis NTT turut mempengaruhi tingkat pendidikan masyarakat di NTT tingkat pendidikan masyarakat di NTT masih tergolong rendah beberapa daerah masih ditemukan penduduk yang buta huruf. Angka buta huruf masih mencapai 9,79\% tahun 2012 terutama pada penduduk dewasa dan lansia Angka melek huruf provinsi NTT mencapai $89,20 \%$ pada tahun 2011.Apabila dibandingkan dengan rata-rata nasional gap sebesar 4,36\% karena rata-rata angka melek huruf tingkat nasional mencapai $93,56 \% .^{2}$

Perilaku masyarakat yang masih terikat adat istiadat dan masih banyak daerah yang belum menikmati listrik sehingga sangat berpengaruh pada pola hidup termasuk dalam hal menyikapi situasi dan kondisi yang terjadi ditambah lagi kurangnya sosialisasi tentang kebijakan pemerintah maupun informasi yang sedang berkembang. Faktor tersebut dimanfaatkan oleh spekulan untuk melakukan aksi penimbunan BBM agar harga melambung yang menimbulkan keresahan dimasyarakat sehingga terprovokasi untuk ikut melakukan aksi penimbunan yang digunakan untuk kebutuhan sehari-hari maupun untuk kegiatan menangkap ikan.

Atas dasar hal tersebut diatas, maka penulis merumuskan beberapa rumusan masalah, yaitu 1) bagaimana upaya pemerintah menanggulangi penyalahgunaan

1. Tulisan ini merupakan hasil penelitian.

2. Provinsi Nusa Tenggara Timur, tersedia di website http://nttprov.go.id/new/index.php/2014-03-13-05-5455/informasi-pendidikan diakses pada tanggal 12 April 2014. 
BBM subsidi di Nusa Tenggara Timur untuk menulis mengenai kebijakan hukum pidana dalam menanggulangi penyalahgunaan BBM subsidi di Nusa Tenggara Timur. 2) Penerapan Kebijakan Formulasi Tindak Pidana Penyalahgunaan BBM Subsidi dan Sanksi Pidana Yang Berlaku Sekarang. 3) Kebijakan formulasi tindak pidana penyalahgunaan BBM subsidi dan penerapan sanksi dimasa yang akan datang.

\section{Metode Penelitian}

Metode pendekatan dalam tulisan ini adalah metode pendekatan yuridis normatif yang dimaknai sebagai suatu prosedur penelitian ilmiah untuk menemukan kebenaran berdasarkan logika keilmuan dipandang dari sisi normatifnya. Selain itu, penelitian yuridis normatif juga dimaknai sebagai suatu penelitian yang berusaha mensinkronisasi ketentuan-ketentuan hukum yang berlaku dalam perlindungan hukum terhadap norma-norma atau peraturanperaturan hukum lainnya dengan kaitannya dalam penerapan peraturan-peraturan hukum itu pada praktik nyatanya di lapangan. ${ }^{4}$

Untuk menunjang diperolehnya data yang aktual dan akurat, penelitian ini didasarkan pada data sekunder yang diperoleh melalui kajian pustaka dengan metode analisis data deskriptif analitis yaitu menggambarkan fakta-fakta tentang objek penelitian baik dalam kerangka sistematisasi maupun sinkronisasi berdasarkan aspek yuridis dan dianalisis, dengan tujuan menjawab permasalahan yang menjadi objek penelitian. ${ }^{5}$

\section{Kerangka Teori \\ a. Kebijakan Kriminal (Criminal Policy)}

Istilah "kebijakan"dalam tulisan ini diambil dari istilah "Policy" (Inggris) atau "politiek" (Belanda). Bertolak dari kedua istilah asing ini, maka istilah kebijakan hukum pidana dapat pula disebut dengan istilah "Politik Hukum Pidana". Dalam kepustakaan asing istilah politik hukum pidana dikenal dengan berbagai istilah, antara lain "penal policy", criminal law policy, atau strafrechtpolitiek. ${ }^{6}$ Sudarto mengemukakan tiga arti mengenai kebijakan kriminal yaitu: ${ }^{7}$

1) Dalam arti sempit ialah keseluruhan asas dan metode yang menjadi dasar dari reaksi terhadap pelanggaran hukum yang berupa pidana.

2) Dalam arti luas ialah keseluruhan fungsi dari aparatur penegak hukum, termasuk didalamnya cara kerja dari pengadilan dan polisi.

3) Dalam arti paling luas keseluruhan kebijakan, yang dilakukan melalui perundang-undangan dan badan-badan resmi, yang bertujuan untuk menegakkan norma-norma sentral dari masyarakat.

Usaha dan kebijakan untuk membuat peraturan hukum pidana yang baik, pada hakikatnya tidak dapat dilepaskan dari tujuan penanggulangan kejahatan. Jadi kebijakan atau politik hukum pidana juga merupakan bagian dari politik kriminal. Dengan perkataan lain, dilihat dari sudut politik kriminal, maka politik hukum pidana identic dengan pengertian kebijakan penanggulangan kejahatan dengan hukum pidana. $^{8}$

Dilihat sebagai bagian dari politik hukum, maka politik hukum pidana mengandung arti, bagaimana mengusahakan atau membuat dan merumuskan suatu perundang-undangan pidana yang baik. Pengertian demikian terlihat pula dalam definisi "penal policy", Mars Ancel yang telah dikemukakan pada uraian secara singkat dapat dinyatakan sebagai " suatu ilmu sekaligus seni yang bertujuan untuk memungkinkan " peraturan hukum positif "

3. Johny Ibrahim, 2005, Teori dan Metodologi Penelitian Hukum Normatif, Surabaya, Bayu Media Publishing, hlm 46.

4. Burhan Ashofa, 2001, Metode Penelitian Hukum, Jakarta, Rineka Cipta, hlm. 15.

5. Bambang Sunggono, 2001, Metodologi Penelitian Hukum Cetakan Ketiga, Jakarta, Raja Grafindo Persada, hlm 116117.

6. Kim So Woong, “Kebijakan Hukum Pidana dalam Upaya Penegakan Hukum Lingkungan Hidup”, Jurnal Dinamika Hukum, Vol. 13, No. 3, September 2013, hlm 416

7. Barda Nawawi Arief, 2008, Bunga Rampai Kebijakan Hukum Pidana, Jakarta, Kencana, hlm 30

8. Bambang Tri Bawono, "Kebijakan Hukum Pidana dalam Upaya Penanggulangan Malpraktik Profesi Medis", Jurnal Hukum, Vol XXV, Issue 1, April 2011, hlm 456 
(the positive rules) dalam definisi Mars Ancel ${ }^{9}$ itu jelas peraturan perundang-undangan hukum pidana. Dengan demikian istilah "penal policy" menurut Mars Ancel adalah sama dengan istilah " kebijakan atau politik hukum pidana “.

\section{b. Kebijakan Hukum Pidana (Penal Policy)}

Penggunaan upaya hukum, termasuk hukum pidana, sebagai salah satu upaya untuk mengatasi masalah sosial termasuk dalam bidang kebijakan penegakan hukum. Disamping itu karena tujuannya adalah untuk mencapai kesejahteraan masyarakat pada umumnya, maka kebijakan penegakan hukum itupun termasuk dalam bidang kebijakan sosial, yaitu segala usaha yang rasional untuk mencapai kesejahteraan masyarakat.

Jika dilihat dalam arti sempit adalah keseluruhan asas dan metode yang menjadi dasar dari reaksi terhadap pelanggaran hukum yang berupa pidana. Dalam arti luas adalah keseluruhan fungsi dari aparatur penegak hukum, termasuk didalamnya cara kerja dari pengadilan dan polisi, dalam arti yang paling luas (yang diambil dari Jorgen Jepse) adalah keseluruhan kebijakan, yang dilakukan melalui perundang-undangan dan badanbadan resmi, yang bertujuan untuk menegakkan norma-norma sentral dari masyarakat.

Menurut Sudarto, Kebijakan kriminal merupakan "suatu usaha yang rasional dari masyarakat dalam menanggulangi kejahatan". Kebijakan atau upaya penanggulangan kejahatan pada hakikatnya merupakan bagian integral dari upaya perlindungan masyarakat (social defense) dan upaya mencapai kesejahteraan masyarakat (social welfare). Tujuan dari politik criminal adalah "perlindungan masyarakat untuk mencapai kesejahteraan masyarakat". Dalam upaya penanggulangan kejahatan "penal" dan "non penal". Pada waktu tertentun (ius contitutum) dan masa mendatang (ius contituendum). Namun kebijakan hukum pidana identik dengan penal reform dalam arti sempit, karena sebagai suatu sistem hukum pidana terdiri dari budaya (cultural), struktur (Structur), dan substantsia (substansive) hukum. Karena undang - undang merupakan bagian dari substansi hukum, pembaharuan hukum pidana, disamping memperbaharui perundang-undangan juga mencakup ide dasar dan ilmu hukum pidana.

Menurut Marc Ancel, ${ }^{11}$ penal policy merupakan ilmu sekaligus seni yang bertujuan untuk memungkinkan peraturan hukum positif dirumuskan secara lebih baik. Peraturan hukum positif diartikan sebagai peraturan perundang-undangan hukum pidana. Usaha dan kebijakan membuat peraturan hukum pidana yang baik, pada hakikatnya tidak dapat dilepaskan dari tujuan penanggulangan kejahatan. Jadi kebijakan atau politik hukum pidana bagian dari politik kriminal. Dengan kata lain dari sudut politik kriminal, politik hukum pidana identik dengan pengertian kebijakan penanggulangan kejahatan dengan hukum pidana. Ruang lingkup kebijakan pidana sebenarnya lebih luas daripada pembaharuan hukum pidana. Kebijakan hukum pidana dilaksanakan melalui tahap-tahap konkretisasi, operasionalisasi, fungsionalisasi hukum pidana yang terdiri dari :

1) Tahap formulasi yaitu tahap penegakan hukum in abstracto oleh badan pembuat undang-undang, tahap ini disebut dengan tahap kebijakan legislatif.

2) Tahap aplikasi yaitu tahap penerapan hukum pidana oleh aparat penegak hukum mulai dari kepolisian sampai ke pengadilan. Tahap ini disebut tahap kebijakan yudikatif.

3) Tahap eksekusi yaitu tahap pelaksanaan hukum pidana secara konkret oleh aparat-aparat pelaksanaan pidana. Tahap ini disebut tahap kebijakan eksekutif atau administratif. ${ }^{12}$

Apabila dilihat dari keseluruhan proses tahap penegakan hukum pidana, tahap kebijakan legislative merupakan tahap paling penting atau tahap paling strategis dari keseluruhan kebijakan untuk

9. Ibidhlm 160

10. Barda Nawawi Arief, 2008, Kebijakan Hukum Pidana Perkembangan Penyusunan Konsep KUHP Baru, Jakarta, Kencana, hlm 112

11. Ibid, hlm 118

12. Ibid hlm 119 
mengoperasionalisasikan sanksi pidana.

B. Hasil dan Pembahasan

1. Upaya pemerintah menanggulangi penyalahgunaan $B B M$ subsidi di Nusa Tenggara Timur

Upaya penegakan hukum sudah dilakukan pemerintah untuk menanggulangi penyalahgunaan BBM subsidi baik secara nasional maupun secara lokal. Untuk ditingkat nasional yaitu dibentuknya tim KP4 BBM (Tim Koordinasi Penanggulangan Penyalahgunaan Penyediaan dan Kontribusi BBM) yang terdiri dari unsur Kepolisian, Jaksa, BPH Migas, Bea Cukai serta dibantu beberapa LSM Lingkungan dan Mineral Tambang.

Sedangkan untuk diwilayah lokal yang berada di provinsi atau kota / kabupaten kordinasi terdiri dari unsur Kepolisian, TNI, Jaksa, Bea Cukai dari unsur Pemerintah Provinsi, Kota atau Kabupaten yaitu dari bagian ekonomi dan Dinas Perindustrian dan Perdagangan serta Satuan Polisi Pamong Praja serta Pertamina dengan cara menentukan sasaran berdasarkan daerah paling rawan penyalahgunaan BBM subsidi. Hasil kegiatan akan didatakan berupa barang bukti maupun tersangka kemudian dilanjutkan ke tingkat penyidikan.

Upaya lain yang dilakukan oleh pemerintah dalam hal penyelundupan BBM subsidi didaerah yang berbatasan langsung dengan Negara Timor Leste yaitu daerah Kab Timor Tengah Utara, Kab. Belu dan Kab Alor dengan cara memperketat penjagaan daerah perbatasan yaitu dengan menempatkan pasukan pengamanan perbatasan dari Yonif 744 / PSY yang menjaga dibeberapa pos perbatasan Kab Timor Tengah Utara serta Kab Kupang sedangkan Yonif 514/Raider Kostrad akan bertugas di Sektor Timur meliputi wilayah Kabupaten Belu dan Kabupaten Malaka. Anggota Satuan Pengamanan Tugas Perbatasan melaksanakan tugas patroli didaerah perbatasan untuk pemeriksaan pelintas batas illegal, penanganan pelintas batas illegal, penanganan masalah peredaran narkoba, illegal logging, illegal mining dan penyelundupan baik BBM maupun kebutuhan pokok lainya. ${ }^{13}$

Sedangkan pengamanan perbatasan perairan seperti diperbatasan Kab Alor yang berbatasan laut pengamanan perbatasan diemban oleh Lantamal VII Kupang dengan menggunakan KRI Teluk Ratai yang berpatroli menjaga perairan dari aksi penyelundupan baik BBM maupun kebutuhan pokok lainnya.

2. Penerapan Kebijakan Formulasi Tindak Pidana Penyalahgunaan BBM Subsidi dan Sanksi Pidana Yang Berlaku Sekarang.

a. Tindak pidana dibidang Minyak dan Gas Bumi dirumuskan pada pasal $51 \mathrm{~s} / \mathrm{d}$ 56, namun mengenai apa yang disebut tindak pidana penyalahgunaan BBM subsidi tidak dirumuskan secara tegas sehingga memungkinkan timbulnya multi penafsiran dibeberapa kalangan. Rumusan unsur-unsur tindak pidana seperti dirumuskan pasal 51 s/d 56 hanya untuk diterapkan kepada pelaku terutama masyarakat yang melakukan kegiatan usaha di bidang minyak dan gas bumi tanpa ijin yang sah.

b. Subyek hukum dalam Undang-undang No.22 Tahun 2001 adalah Orang dan Korporasi (badan hukum atau badan usaha).

c. Sanksi pidana, Penerapan sanksi pidana dirumuskan secara kumulatif bersifat kaku dan imperatif ancaman pidana yang dikenakan sama antara pelaku perorangan dengan korporasi. Oleh karena itu menjadi masalah apabila yang dipidana " korporasi " yang dijatuhi pidana denda. Dalam undangundang ini tidak ada ketentuan khusus mengenai pidana pengganti untuk denda yang tidak dibayar. Dan pidana denda diancamkan adalah denda maksimal tidak dijelaskan denda minimal untuk pelanggaran dengan

13.Tersedia di website http://www.divif2kostrad.com/brigif-9/brigif-92-kostrad/latihan-pratugas-yonif514r9nbsp.html, diakses pada tanggal 13 Mei 2015

14. Ibid 
nomimal atau jumlah liternya yang sedikit. Didalam Undang-Undang 22 Tahun 2001 Tentang Minyak dan Gas Bumi menerapkan sanksi secara kumulatif tetapi pada penjatuhan putusan oleh hakim menggunakan putusan alternatif apabila terdakwa tidak mampu membayar denda maka diganti dengan pidana penjara.

d. Pertanggungjawaban pidana korporasi, dalam hal pertanggungjawaban pidana untuk korporasi tidak dijelaskan dan tidak disebutkan mengenai dalam hal bagaimana korporasi dikatakan telah melakukan tindak pidana dan korporasi dapat dipertanggungjawabkan.

e. Penerapan Sanksi Pidana

Penerapan sanksi pidana terhadap tindak pidana dibidang Minyak dan Gas Bumi dikenakan sebagaimana rumusan dalam Pasal 51 s/d 56 mengenai ketentuan pidana, pengenaan sanksi yaitu :

1. Pidana Penjara

2. Denda

3. Pencabutan hak atau perampasan barang yang digunakan untuk atau yang diperoleh dan tindak pidana dalam kegiatan usaha minyak dan gas bumi

Hal ini menunjukkan ancaman pidana dalam tindak pidana ini termasuk kategori berat, dalam aplikasinya pasal ini diterapkan secara umum tidak pandang bulu, kepada pelaku tindak pidana penyalahgunaan BBM subsidi yang melaksanakan kegiatan usaha dibidang minyak dan gas bumi tanpa ijin untuk sekedar memenuhi kebutuhan ekonomi ataupun para pemain besar yang mengambil keuntungan besar dari usaha dibidang minyak dan gas bumi tanpa ijin yang sah dari pejabat yang berwenang.

Maksud dan tujuan dari pemberian sanksi pidana yang berat terhadap setiap orang yang melanggar hukum dibidang minyak dan gas bumi ini adalah agar dapat menimbulkan efek jera bagi pelanggar hukum dibidang minyak dan gas bumi. Efek jera dimaksud bukan hanya kepada pelaku yang telah melakukan tindak pidana, akan tetapi kepada orang lain yang mempunyai kegiatan dalam bidang minyak dan gas bumi menjadi enggan melakukan perbuatan melanggar hukum karena sanksi berat yang diancamkan.

\section{Kebijakan formulasi tindak pidana penyalahgunaan $B B M$ subsidi dan penerapan sanksi dimasa yang akan datang.}

a. Formulasi Kebijakan tindak pidana minyak dan gas bumi

Hal ini berkaitan dengan beberapa hal yang perlu dievaluasi yakni tentang:

(1) Definisi Tindak pidana dibidang minyak dan gas bumi, definisi tindak pidana dibidang minyak dan gas bumi perlu dirumuskan secara tegas dalam undangundang sehinga tidak menimbulkan multi tafsir dari berbagai kalangan.

(2) Subjek hukum tindak pidana dibidang minyak dan gas bumi

Berdasarkan perumusan pasal mengenai ketentuan tindak pidana dibidang minyak dan gas bumi diatur pada pasal $51 \mathrm{~s} / \mathrm{d} 56$ UU No.22 Tahun 2001 tentang Minyak dan Gas Bumi, subjek tindak pidana adalah orang dan badan hukum atau badan usaha (korporasi) sebaiknya dirumuskan juga tindak pidana terhadap pejabat atau pegawai negeri yang mempunyai kewenangan dalam bidang minyak dan gas bumi yang berpotensi melakukan penyalahgunaan kewenangan.

Subjek hukum adalah orang perorangan dan korporasi sementara ini perumusan tindak pidana kedua subjek hukum tersebut diatur dalam satu pasal yang sama dengan satu ancaman pidana yang sama pula sebaiknya hal ini dipisahkan masing-masing diatur dalam satu pasal yang tersendiri demikian pula mengenai sanksi pidana yang dijatuhkan diatur dalam pasal tersendiri pula.

(3) Masalah Perumusan Sanksi Pidana

Sanksi pidana sebaiknya tidak dirumuskan secara kumulatif yang bersifat imperatif/kaku, namun dirumuskan secara alternatif untuk memberi keleluasaan kepada hakim dalam menjatuhkan vonis kepada pelaku.

(4) Pertanggungjawaban pidana korporasi

Ditegaskannya tindakan administratif ke dalam sistem pertanggungjawaban pidana 
untuk korporasi dengan menyebutkan mengenai kapan atau dalam hal bagaimana korporasi dapat dipertanggungjawabkan seyogyanya dilengkapi pula dengan aturan khusus yang ditujukan kepada korporasi mengenai pidana pengganti denda yang tidak dibayar.

b. Penerapan sanksi pidana

Pengenaan sanksi pidana disamping dijatuhkan sanksi pidana secara kumulatif, mengingat dampak/akibat dari tindak pidana dibidang minyak dan gas bumi ini merugikan keuangan Negara, ekonomi dan sosial maka hendaknya pemberian sanksi tidak hanya sebuah sanksi pidana kepada pelaku dengan sanksi yang seberat-beratnya tetapi lebih kepada pemberian contoh kepada masyarakat ataupun badan usaha untuk tidak melakukan tindak pidana dibidang minyak dan gas bumi.

Disamping itu untuk memenuhi perasaan keadilan hendaknya perumusan sanksi pidana tindak pidana dibidang minyak dan gas bumi yang dilakukan oleh pegawai negeri atau aparat pemerintah terutama kepada pejabat yang mempunyai kewenangan dalam bidang minyak dan gas bumi yang berpotensi melakukan penyalahgunaan diatur dan dirumuskan secara khusus yang perumusan sanksi pidananya tidak sama dengan orang atau pribadi.

\section{Simpulan}

Berdasarkan uraian pembahasan di atas, maka dapat disimpulkan sebagai berikut:

1. Upaya pemerintah dalam menanggulangi penyalahgunaan $\mathrm{BBM}$ subsidi di NTT dengan cara membentuk tim kordinasi yang terdiri dari unsur Kepolisian, TNI, Kejaksaan, Pertamina, Bea Cukai, SatPol PP serta menggandeng LSM. Upaya lainnya yaitu menjaga perbatasan dengan pasukan dari TNI yang menjaga perbatasan RI dengan Timor Leste.

2. Dalam ketentuan pidana yang terdapat di Undang-undang No.22 Tahun 2001 tentang Minyak dan Gas bumi menganut sistem kumulatif, penjatuhan pidana kepada pelaku yaitu pidana penjara dan denda. Sedangkan pada putusan hakim terhadap kasus pelanggaran Undang-undang No.22 Tahun 2001 Tentang Minyak dan Gas Bumi menerapkan pidana alternatif penjatuhan pidana penjara dan atau denda sehingga apabila terdakwa tidak membayar denda maka diganti dengan pidana penjara.

3. Hal yang perlu dievaluasi yakni tentang: Definisi tindak pidana dibidang minyak dan gas bumi perlu dirumuskan secara tegas dalam undang-undang sehinga tidak menimbulkan multi tafsir dari berbagai kalangan.

subjek tindak pidana adalah orang dan badan hukum atau badan usaha (korporasi) sebaiknya dirumuskan juga tindak pidana terhadap pejabat atau pegawai negeri yang mempunyai kewenangan dalam bidang minyak dan gas bumi yang berpontensi melakukan penyalahgunaan kewenangan. Sanksi pidana sebaiknya tidak dirumuskan secara kumulatif yang bersifat imperatif/kaku, namun dirumuskan secara alternatif untuk memberi keleluasaan kepada hakim dalam menjatuhkan vonis kepada pelaku.

Pengenaan sanksi pidana disamping dijatuhkan sanksi pidana secara kumulatif, mengingat dampak/akibat dari tindak pidana dibidang minyak dan gas bumi ini merugikan keuangan Negara, ekonomi dan sosial maka hendaknya pemberian sanksi tidak hanya sebuah sanksi pidana kepada pelaku dengan sanksi yang seberatberatnya tetapi lebih kepada pemberian contoh kepada masyarakat ataupun badan usaha untuk tidak melakukan tindak pidana dibidang minyak dan gas bumi.

Disamping itu untuk memenuhi perasaan keadilan hendaknya perumusan sanksi pidana tindak pidana dibidang minyak dan gas bumi yang dilakukan oleh pegawai negeri atau aparat pemerintah terutama kepada pejabat yang mempunyai kewenangan dalam bidang minyak dan gas bumi yang berpotensi melakukan 
penyalahgunaan diatur dan dirumuskan secara khusus yang perumusan sanksi pidananya tidak sama dengan orang atau pribadi.

\section{Daftar Pustaka}

Ashofa Burhan 2001, Metode Penelitian Hukum, Jakarta, Rineka Cipta

Bawono Bambang Tri, Kebijakan Hukum Pidana dalam Upaya Penanggulangan Malpraktik Profesi Medis, Jurnal Hukum, Vol XXV, No. 1, April 2011

Ibrahim Johny, 2006, Teori dan Metodologi Penelitian Hukum Normatif, Surabaya, Bayu Media Publishing.

Nawawi Arief Barda, 2008, Bunga Rampai Kebijakan Hukum Pidana, Jakarta, Kencana

Nawawi Arief Barda, 2008, Kebijakan Hukum Pidana Perkembangan Penyusunan Konsep KUHP Baru, Jakarta, Kencana.

So Woong Kim, Kebijakan Hukum Pidana dalam Upaya Penegakan Hukum Lingkungan Hidup, Jurnal Dinamika Hukum, Vol. 13, No. 3, September 2013

Sunggono Bambang, 2001, Metodologi Penelitian, Cetakan Ketiga, Jakarta, Raja Grafindo Persada

Provinsi Nusa Tenggara Timur, tersedia di website http://nttprov.go .id/new/index.php/2014-03-13-0554-55/informasi- pendidikan, diakses pada tanggal 12 April 2014

Tersedia di website http://www .divif2kostrad.com/brigif-9/brigif92-kostrad/latihan-pratugas-yonif514r9nbsp.html, diakses pada tanggal 13 Mei 2015

Undang-Undang Nomor 22 Tahun 2001 Tentang Minyak dan Gas Bumi 